JPE (Jurnal Pendidikan Edutama) Vol. 6 No. 2 Juli 2019

P-ISSN : 2339-2258 (Print) E-ISSN: 2548-821X (Online)

http://ejurnal.ikippgribojonegoro.ac.id/index.php/JPE

\title{
ANALYZING STUDENT TEACHERS OF ENGLISH LISTENING FLUENCY LEVEL: A PRELIMINARY RESEARCH Refi Ranto Rozak ${ }^{1)}$, Mursid Saleh ${ }^{2)}$, Dwi Anggani Linggar Bharati ${ }^{3)}$, Djoko Sutopo ${ }^{4)}$ \\ ${ }^{1}$ Post Gradute Program, English Education Department, Universitas Negeri Semarang (UNNES) and Faculty of Language and Arts Education, IKIP PGRI Bojonegoro ${ }^{2,3,4}$ English Education Department, Universitas Negeri Semarang (UNNES) 1email: refi.ranto@ikippgribojonegoro.ac.id, ${ }^{3}$ dwi_anggani@mail.unnes.ac.id djoko.sutopo@mail.unnes.ac.id
}

\begin{abstract}
Although listening comprehension remains a widely acknowledged tool for assessing and evaluating student teachers' achievement in mostly Indonesian initial teacher education (ITE) context, the issue of listening fluency (LF) as one of the four strands of well-balanced language course has not received scholarly attention. However, in fact, LF is important for developing their automatic aural processing on authentic exposures. In response to this gap, this article discussed the result of LF test via graded serial news stories in normal speech rates to 60 English student teachers of a private ITE institution in the northern part of East Java Province, Indonesia, to examine their $L F$ levels. Additionally, various responses of $L F$ experience, massive spoken texts experience, spoken features inhibition, and LF instruction evaluative feedbacks were garnered as additional qualitative data via interview responses at the end of the research as well. The data obtained were then tabulated, categorized, and analyzed. The finding of the research mainly found that, on average, their LF score was 66. It reveals that their LF level was under the normal speech rate required in longer aural texts found in real-life listening. The findings may raise the awareness of possibility including $L F$ in the prescribed listening curriculum for training student teachers' language proficiency.
\end{abstract}

Keywords: Listening, listening comprehension, fluency, listening fluency, student teacher

\begin{abstract}
Abstrak
Walaupun pemahaman menyimak secara luas dikenal sebagai alat penilaian dan evaluasi prestasi mahasiswa calon guru di hampir semua institusi pendidikan calon guru di Indonesia, isu kelancaran menyimak sebagai salah satu dari empat pilar program bahasa yang berimbang belum secara ilmiah mendapat perhatian. Meskipun demikian, kelancaran menyimak dirasa penting untuk mengembangkan proses pemahaman teks lesan otentik secara otomatis. Oleh karena itu, artikel ini memaparkan hasil tes menyimak via teks lesan berita serial berjenjang dalam tingkat kecepatan normal terhadap 60 mahasiswa calon guru bahasa Inggris di sebuah institusi keguruan di bagian utara Provinsi Jawa Timur untuk menguji tingkat kelancaran menyimak mereka. Selain itu, beragam respons pengalaman mahasiswa tentangkelancaran menyimak, pengalaman menyimak teks lesan masif, hambatan-hambatan dalam bahasa lesan, dan umpan balik evaluatif terkait pengajaran kelancaran menyimak dikumpulkan sebagai data kualitatif melalui wawancara di akhir penelitian. Data yang telah diperoleh kemudian ditabulasi, dikategorisasi, dan dianalisa. Temuan utama penelitian ini adalah kelancaran menyimak mahsiswa calon guru bahasa Inggris rata-rata masih rendah, yaitu sebesar 66. Hal ini berarti tingkat kelancaran menyimak mereka masih di bawah tingkat kecepatan normal yang dipersyaratkan dalam memahami teks lesan panjang dalam situasi menyimak sehari-hari. Temuan ini menumbuhkan kesadaran akan kemungkinan memasukkan kelancaran menyimak dalam kurikulum menyimak untuk melatih kemahiran berbahasa mahasiswa calon guru bahasa Inggris.
\end{abstract}

Kata kunci: Menyimak, pemahaman menyimak, kelancaran, kelancaran menyimak, mahasiswa calon guru 


\section{INTRODUCTION}

In current scholarly literature on ESL/EFL listening in tertiary education, there has been a growing need for the inclusion of listening fluency (LF) (Chang, 2011; Chang \& Millet, 2014; Chang \& Millet, 2016; Chang, Millet \& Renandya, 2018). The notion of including LF in listening instruction comes from the awareness of teachers in the absence of students' ability in comprehending the natural speech rates uttered in communicative discourses. In this regard, they experienced comprehending the longer speech of spoken language in a different situation. Although the texts are spoken in normal speed or even at slow speed, they perceived the texts too fast. This is because they lack constant exposures delivered at normal speech rates with different accents and language use (Chang, 2011). Therefore, the natural spoken language determined by the speakers in listening activities and their ability level to process the language input is not comparable.

In natural language input processing, they are frequently forced to listen to the spoken texts naturally between 150 to 180 words per minutes (WPM). Consequently, they mostly fail to catch the meaning in those listening rate level because their LF is under those normal levels. Therefore, the failure to catch the aural language naturally in larger language input influences their comprehension. Although comprehension is a key to language acquisition, LF cannot be ignored because it promotes comprehension and they are interrelated (Chang, 2011). The more fluent their LF means the higher their comprehension level at normal speed rate. With this reason, LF should be a crucial issue in listening instruction.
Accordingly, the limited comprehensible input during listening activities in the classroom may cause the inability to communicate competently in English when the class ends (Gobel et al., 2013; Yoshida, 2013).

In general, LF can be characterized as listeners reasonably understanding aural input delivered at a normal speed effortlessly and accurately (Chang \& Millet, 2016). In the classroom context, LF can be facilitated through listening to the massive exposure of spoken texts for meaning. In this regard, comprehensible inputs through listening for pleasure are beneficial for enhancing students LF because they comprehend the structures and vocabulary for attaining general comprehension of the texts. Theoretically speaking, comprehensible inputs for increasing LF are obtained from listening to large quantities of aural target language input that interests them and is within their linguistics competence (Renandya \& Farrel, 2011; Yeh, 2013).

Additionally, they do a process in which the results of an action are fed back to achieve greater results more quickly and with less effort relying on comprehensible and enjoyable listening input. For that reason, they are exposed to a large amount of texts that are reasonably and smoothly relevant to their language proficiency level (Vo, 2013). More importantly, they do listening because they need it to access information (listen to learn) according to their own pace and fluency. By this in mind, the success of comprehending spoken text in listening depending on the inputs not only from the classroom atmosphere but outside the classroom for pleasure listening. 
In the initial teacher education (ITE) context, LF is a very novel idea. Even though LF has been discussed and researched in L2 context it is unfortunate that LF assessment has not received scholarly attention in the literature of EFL context. Teacher educators never test their LF levels in their listening practices. In response to these gaps of the literature, it is indispensable for teacher educators conducting LF test in listening instruction of student teachers training and education to know their listening speed in processing longer aural texts.

This article is the preliminary research of the first writer dissertation writing in promoting LF. It examined the level of student teachers' LF in an ITE context. It aims at measuring the level of their LF before the writers employed various inputs to build automation on the extended listening for meaning making. Additionally, the result of the analysis would be used to determine further LF activities and materials along with engaging LF activities. To present a clear picture of student teachers LF levels, this article addresses such questions as: 1) What are the student teachers of English LF levels in listening to graded serial news stories?; and 2) What are the students teachers of English understanding on $\mathrm{LF}$, their experiences in listening to massive spoken texts, spoken features inhibition, and their evaluative feedbacks on LF instruction?

\section{RESEARCH METHODOLOGY}

The research was conducted at an English Education Department of a private ITE, in the northern part of East Java Province, Indonesia. The department was part of the first writer research dissertation setting. Annually, it receives 60-80 students for being trained as student teachers of English. Listening as a part of courses offered in the Department generally teaches student teachers to have good comprehension on English spoken texts start from beginner level to advanced level and train them how to use the strategies and skills in teaching listening for preparing their career as English teachers in junior and senior high schools.

More specifically, there are three prescribed listening courses offered in the department: Listening for Daily Context, Listening for Social Issues, and Academic Listening. In Listening for Daily Context, student teachers are trained on how to learn to listen to shorter bits of spoken language intensively which adopt comprehension approach. In Listening for Social Issues, they are trained to focus on listening exercises by identifying general and specific information of authentic and non- authentic materials in an upper intermediate and pre-advanced level using a top-down approach. Meanwhile, in Academic Listening, they are provided with listening practices in which they learn identifying general and specific information of long lectures with various fields.

This research was part of Academic Listening course. This fluency activity took a quarter of class time or approximately 1,5 of 6 odd semester duration academic year 2017/2018. It aimed at practicing student teachers to learn listening and listening to learn longer pieces of spoken language in authentic materials using various inputs. In addition, 60 student teachers $($ male $=15$, female $=45)$ involved in the research. 12 participants agreed to have a one-to-one interview to report their experience during listening to extended listening. 
The source of the data obtained from LF test containing multiple-choice (MC) 45 items. The speech rate was set at $160 \mathrm{wpm}$ (word per minute) which is considered to be normal speed (Buck, 2001, Griffiths, 1990). The MC items required student teachers to listen to the questions and read the four options. Student teachers answering one item correctly gained one point and the incorrect answer was counted as zero. LF is measured by the comprehension level of aural input that is delivered at a normal speech rate rather than at an unnaturally adjusted slow speed (Chang, 2011). More additionally, the data were obtained from student teachers' responses in the interview section. The topics of the interview mainly were student teachers' initial understanding of LF, student teachers' experiences in listening to massive spoken inputs, the spoken features inhibition in listening to graded serial news stories, and evaluative feedbacks on LF instruction in the prescribed listening curriculum. Therefore, it is expected that the writers would obtain some causal information dealing with LF test.

The student teachers' LF test scores were analyzed based on the total number of correct items in graded serial news stories. If they correctly answered above 70 or above meaning that their LF level was at a normal speed rate. As Chang, Millet, and Renandya (2018) suggested fluent listeners are able to maintain a reasonable comprehension level (e.g. $70 \%$ or more) for an extended period of time and to comprehend a variety of spoken texts. On the contrary, if their LF test scores were below 70 or less meaning that they had slower LF levels. The higher the comprehension level means the more fluent is the listening process.

More additionally, student teachers' responses in a one-to-one interview were analyzed through coding data. It was obtained by reading intervew transcriptions in order to generate codes or categories. The coding was conducted to overview the underlying codes of events and experiences that the participants encountered, behaviors, and actions they took. For example, the following data: "I could not catch what the speaker talked about because his speech is too fast......" was grouped into a theme called "the difficult features of spoken texts in graded serial news stories". Thus, the choice of lexical wording was viewed as the mitchmatching strategy to compare and triangulate until the data were saturated.

\section{FINDINGS AND DISCUSSION}

Drawing on LF test scores and interview responses, the findings of the research were identified. The scores of student teachers' LF tests in the first finding were tabulated in Table 1. The overall LF tests scores in Table 1. were then calculated and divided by the total number of the attended student teachers' in LF test $(n=60)$. Additionally, the data obtained from the interview section were classified into themes which reflect the central second research question.

1. Student Teachers Listening Fluency Level in Listening to Graded Serial News Stories 
Table 1. Student Teachers Listening Fluency Scores

\begin{tabular}{clcclc}
\hline No. & Participants & LF Scores & No. & Participants & LF Scores \\
\hline 1. & NS & 33 & 31. & AA & 71 \\
\hline 2. & NR & 33 & 32. & AB & 71 \\
\hline 3. & AHR & 36 & 33. & AEA & 71 \\
\hline 4. & MI & 36 & 34. & DK & 71 \\
\hline 5. & NDP & 36 & 35. & ARP & 73 \\
\hline 6. & RAF & 38 & 36. & JCL & 73 \\
\hline 7. & SSM & 38 & 37. & DSS & 73 \\
\hline 8. & CSD & 51 & 38. & ODW & 73 \\
\hline 9. & SK & 51 & 39. & SANA & 73 \\
\hline 10. & YNW & 53 & 40. & ADK & 76 \\
\hline 11. & IKG & 56 & 41. & ISW & 76 \\
\hline 12. & PPD & 58 & 42. & DAB & 76 \\
\hline 13. & ADCW & 58 & 43. & KS & 76 \\
\hline 14. & SRA & 60 & 44. & WR & 76 \\
\hline 15. & DRS & 62 & 45. & BAS & 76 \\
\hline 16. & MIA & 62 & 46. & DABI & 78 \\
\hline 17. & ZN & 62 & 47. & NS & 78 \\
\hline 18. & N & 62 & 48. & NAA & 78 \\
\hline 19. & KN & 64 & 49. & EH & 78 \\
\hline 20. & LP & 64 & 50. & AN & 78 \\
\hline 21. & MZN & 64 & 51. & HR & 80 \\
\hline 22. & MJ & 67 & 52. & AI & 80 \\
\hline 23. & RAB & 67 & 53. & MAP & 80 \\
\hline 24. & RNK & 67 & 54. & MRT & 82 \\
\hline 25. & YPD & 53 & 55. & MAWP & 82 \\
\hline 26. & IAR & 56 & 56. & ASS & 82 \\
\hline 27. & ARE & 62 & 57. & HH & 84 \\
\hline 28. & TYDP & 67 & 58. & YIA & 84 \\
\hline 29. & HS & 67 & 59. & RNP & 87 \\
\hline 30. & YMA & 67 & 60. & INFMH & 87 \\
\hline & & Total Score & & & 3973 \\
\hline & Average & & & 66 \\
\hline & & & & \\
\hline & & & & \\
\hline
\end{tabular}

As shown in Table 1, the average student teachers' LF test scores at a normal speech rate are 66 . The result of this calculation indicates that their comprehension was influenced by the level of listening to news stories speech rate. In this reason, they failed to process the general meaning of the texts because speakers talked to fast $(n=30)$. Finding difficulty with fast speech rate with EFL listening is variable affecting their comprehension (Renandya \& Farrell, 2011). The decrease in comprehension may be affected by the failure to recall some information in their short-term memory. The data also showed that half of the student teachers in the research have medium to high comprehension $(\mathrm{n}=30$, score intervals= 71-87). It indicates that although the news stories were played in normal speech rate, they were able to listen with fewer barriers because they have different learning styles. Zhao (1997), however, pinpointed that different individuals may perceive the same rate differently due to varying learning styles and language proficiencies. Student teachers' listening styles deal with how they could use various strategies such as previewing the MC items before listening, note-taking, and background knowledge connection of the topics. 
2. Student Teachers LF Understanding, Massive Spoken texts Experience, Spoken Features Inhibition, and LF Instruction Evaluative Feedbacks

Drawn on Table 1, the data were garnered from 12 student teachers' (male $=4$, female $=8)$ LF test scores. Their responses were tabulated, categorized, and analyzed for showcasing the findings. Student teachers' responses on a one-to-one interview were explored according to their prior, during, and future experience in listening to massive spoken texts. The different data obtained from these interviews are important to know the causal events of the research as the responses may be derived from various reasons and background knowledge. This grounded qualitative exerts could be additional data completing the main quantitative data. With this in mind, the results of the research are complex and naturalistic.

To begin with, HH commented, "I understand little about listening fluency. What I understand is speaking fluency. In my opinion, listening fluency deals with the ability to listen to what the speakers say fast. I just heard this term in this research." LP also remarked that "listening fluency is an important listening skill. We cannot understand well listening to spoken texts in real-life listening if we do not practice our fluency as the speakers mostly speak fast." YNW responded, "Listening fluency is something new in listening. There is a strong correlation between listening fluency and comprehension. If I listen to songs repeatedly, for instance, I will soon understand the messages inside.

Additionally, listening to fluency cannot be understood once. It should be repeatedly trained regularly." The more
I practice, the more I get used to listening to similar pieces of spoken texts. HH and LP comments reflected their awareness on the importance of communicative language teaching that fosters them to use English fluently and effectively. This idea encourages student teachers to communicatively use language as a means of interaction which needs a natural flow of listening processing (Fang, 2012; Yoshida, 2013). In addition, YNW saw the role of listening support, for example, multiple or repeated listening in helping their comprehension. Listening several times allow learners to process the input more times (Chang, 2018). Furthermore, after listening to the text several times, some parts of the text will become automatic (Anderson, 1990).

The second issue of the interview was their experiences in listening to massive spoken inputs. MRT argued that "mostly classroom listening materials are guided by listening teacher educator. I rarely listen to longer dialogues and monologues. What I have learned is about materials in the textbook. Supplemental longer spoken texts is also given but with the limited portion." Widodo \& Cirocki (2015) pinpoint that listening instruction has been framed based on ESL published textbooks whose contents are inappropriate for students. Such textbooks may contain some intensive listening tasks and require learners to answer comprehension questions without any meaningful and interactional activities.

The materials and activities inside the textbooks do not support LF training which encourages learners to listen to massive listening materials at normal speed rate because under the learners' language proficiency. Accordingly, choosing interesting materials which 
suit learners' language competence motivates them to keep listening (Chang \& Millet, 2014). KS added, "I remembered listening assignment once the listening teacher educator gave to me. It trained me viewing skill in TedTalk. I like this activity because it was a test free. I just searched the short video I liked much on TedTalk. He did not permit me to see the subtitles. At the end of the assignment, I should resume the content of the video. This listening activity is worth considering for general comprehension and pleasurable listening." Takaesu (2013) found that TedTalk as listening material along with scaffolded activities increased lower-proficiency students listening comprehension, motivation, and variety of English accents.

More importantly, it enables them to listen to materials according to their LF levels. Contrarily, providing massive spoken sources are indispensable for maintaining student teachers speech rate (Chang, 2018). Allocating a little portion of massive spoken sources and using textbooks too much will hamper student teachers' LF. For example, SK replied, "I think listening to massive spoken texts are sometimes given such as songs, short presentation videos, and podcasts as short programs. However, those listening opportunities portions are very small. I cannot catch the meaning of the materials because they are too difficult.

The third issue of the interview was the difficult features of spoken texts in graded serial news stories. Student teachers' responses were garnered after they had listened to graded serial news stories as the massive exposures. NDP felt worried listening to the fast rates of the anchors in news stories. She claimed that she could not do note-taking because every word was uttered so quickly. However, she was surprised knowing at the end of the test that the written words of the news stories were actually familiar for her. In fact, students are not able to understand the amount of the information not because the content or the language which is too difficult, but the speaker speaks too fast (Renandya \& Jacobs, 2016).

DSS added NDP's grouser that the connected speech was a serious problem to her comprehension. She admitted that words often take on different forms such as head of - headof (joined sound), that - tha' (lost sound), we're - wir (contraction), want to wanna (assimilation), etc. Renandya and Farrell (2011) stated that words often take on different forms from when they are said in isolation. Therefore, some student teachers were not able to distinguish speech blending phenomena when they listened to aural texts, moreover, at a fast speed rate. Similarly, NS argued that common language features of spoken form such as fillers, fixed-phrases, and slangs were less familiar. More additionally, she did not understand the topics of news stories because they were not familiar even when the audio was played several times.

Lastly, student teachers' future feedbacks were also addressed to accommodate their learning needs in LF. Expectedly, learning innovation in listening classrooms would pay careful attention to student teachers' needs because they are the ones who know well their learning ability, what kinds of learning materials they should select along with their teacher educators, and learning objectives they want to achieve. Both NS and AA, for instance, would agree to insert fluency as a competence besides comprehension in 
the listening curriculum. Therefore, teacher educators should have clear and well-articulated guidelines in arranging the learning objectives, the resources, time frame, the way the program is carried out, and the assessment as the tool to measure student teachers' success.

Given the importance of quantity for fluency development, setting out listening activities to large amounts of spoken text should be promoted and encouraged (Renandya \& Jacobs, 2016). Additionally, BAS, WR, and NAA had similar opinions dealing with LF existence in listening classrooms for future training. They admitted that if the amount of exposures is the crucial factor in LF so that teacher educators should provide massive listening materials along with their engaging activities for making-meaning both inside and outside the classrooms.

\section{CONCLUSIONS}

The article has looked at the result of the LF test scores to portray ITE student teachers LF levels in listening to graded serial news stories. In addition, qualitative description on their LF understanding, massive spoken texts listening experience, spoken features inhibition, and LF instruction evaluative feedbacks have also been discussed. On overage, the scores of the LF test shows that their LF level was under normal speech rate (average score $=66$ ). The inability of processing longer aural texts in normal speech rate may cause their comprehension. However, more specifically, the result of the test also shows that $50 \%$ of the student teachers obtain relatively good LF test scores. It indicates that the normal speech rate of graded serial news stories was understandable.
Furthermore, the result of the research also reveals some additional findings. Firstly, student teachers' LF understanding. LF is a part of listening skill. It is highly needed to be trained for comprehending the fast rate of speakers communication found in reallife listening. Some student teachers admitted that the role of LF for comprehension. Gradual LF training, multiple inputs, and repeated listening are contributing factors for the success of LF. Such promotional efforts were expected to practice their spoken language processing and to enhance their LF.

Secondly, student teachers' experience in listening to massive spoken texts was the crucial issue of the LF. As massive spoken inputs are important to support student teachers LF fluency development, the role of materials cannot be ignored. However, the findings revealed that textbooks remain the main center of listening material although its content does not support student teachers LF. They train student teachers' intensive listening by answering comprehension questions at the end of the lesson. Additionally, the speech level in textbooks was not appropriate for student teachers' LF level. Some textbooks may contain high LF which does not suit to low language proficiency student teachers. TedTalk was an example of a good listening source which is in line with their need in enhancing LF. Teaching LF using Tedtalk as an extensive listening (EL) source along with engaging tasks may help them promote LF. They could control and improve their LF level anytime through the self-selected Tedtalk listening for pleasure videos.

Thirdly, spoken features inhibition influencing student teachers' LF comprised of the phenomena of fast 
speech rate, connected speech problems, and unfamiliar topics. $50 \%$ of student teachers $(n=30)$ LF scores were low (average score $=55$ ). It indicates that they failed to comprehend the serial graded news stories in fast speech rate. Furthermore, joined sounds, contraction, and assimilation in spoken language were the problems in listening to aural longer texts besides fast speed. The inability of recognizing the topic was also the contributing factor student teachers failure in comprehending longer spoken texts in fast speed. Indeed, topic familiarity was helpful to recall their previous knowledge. If the topic was familiar, they might also be familiar with the vocabulary and the structures of the topic.

Lastly, student teachers admitted that inserting LF in listening curriculum is important. It aims to train their skill in processing spoken inputs found in real-listening. However, they suggested that well-articulated objectives, resources, time frame, and assessment determined the success of LF development. Moreover, providing massive exposures of aural texts and the activities stimulating their LF should also be carefully planned both inside and outside the classroom without relying too much upon the existing textbooks.

In closing, given the importance of LF in ITE context is beneficial to change the listening paradigm from teaching listening for comprehension to teaching listening for meaning-making. In this regard, providing massive and comprehensible spoken inputs for LF development tasks become an urgent agenda for teacher educators. Listening instruction in tertiary education should not only mold student teachers pedagogical and content knowledge but also train their skills to be proficient
English teachers. By inserting LF in the prescribed curriculum, they start considering LF as a listening aspect which is pivotal and legitimate. LF instruction may be allocated at an advanced listening course because their comprehension of smaller pieces of spoken language has been learned in previous bottom-up listening courses.

Future research is worthappreciated to fill the drawbacks of the research. Since this research has revealed the significant results of student teachers' LF levels, further empirical research with different educational levels and other types of authentic listening materials with bigger population are needed. More additionally, future research may investigate some listening inputs which encourage LF development and how the findings influence students comprehension. The suggested future research agendas would provide more empirical evidence for enriching listening practice especially on LF in various educational settings.

\section{ACKNOWLEDGMENT}

This article is a part of dissertation work of the first author. It was supported by a grant obtained from Direktorat Riset dan Pengabdian Masyarakat, Direktorat Jenderal Penguatan Riset dan Pengembangan, Kementrian Riset, Teknologi, dan Pendidikan Tinggi (Contract Number: 083/SP2H/LT/K7/KM/2018.

\section{BIODATA}

Refi Ranto Rozak teaches student teachers of English at the Department of English Education of IKIP PGRI Bojonegoro, East Java. $\mathrm{He}$ is also currently doing a $\mathrm{PhD}$ in English 
Education at Universitas Negeri Semarang based in Central Java, Indonesia. He holds an MA in English Education from Universitas Sebelas Maret Surakarta based in Central Java, Indonesia. His research interests lie in the teaching of intensive and extensive listening, intensive and extensive reading, bilingual learning, and technology-enhanced language learning (TELL).

\section{REFERENCES}

Anderson, J. R. (1990). Cognitive Psychology and Its Implications: Third Edition. New York: Freeman.

Buck, G. (2001). Assessing Listening. Cambridge, UK: Cambridge University

Press.

Chang, A. C-S. (2011). The effect of reading while listening to audiobooks: Listening fluency and vocabulary gain. Asian Journal of English Language Teaching, 21, 43-64.

Chang, A. C-S., \& Millett, S. (2014). The effect of extensive listening on developing L2 listening fluency: Some hard evidence. ELT Journal, 68(1), 31-40. https://doi.org/10.1093/elt/cct052

Chang, A. C-S., \& Millet, S. (2016). Developing L2 listening fluency through extended listeningfocused activities in an extensive listening programme. RELC Journal, 47(3), 349-362. https://doi.org/10.1177/00336882 16631175
Chang, A. C-S., Millet, S. \& Renandya, W. A. (2018). Developing listening fluency though supported extensive listening practice. RELC Journal, OO(0), 117.

https://doi.org/10.1177/00336882 17751468

Chang, A. C-S. (2018). Speech rate in second language listening. In The TESOL Encyclopedia of English Language Teaching, First Edition. John Wiley \& Sons, Inc. https://doi.org/10.1002/97811187 $\underline{84235 . \text { eelt } 0576}$

Fang, X. (2012). Teaching the new English curriculum in a Chinese school: An ethnographic study. In T. Muller, S. Herder, J. Adamson \& P. S. Brown (Eds), Innovating EFL Teaching in Asia (pp. 9-22). London: Palgrave Macmillan.

Gobel, P., Thang, S. M., Sidhu, G. K., Oon, S. I., \& Chan, Y. F. (2013). Attributions to success and failure in English language learning: A comparative study of urban and rural undergraduates in Malaysia. Asian Social Sciences, 9(2), 53-62. https://doi.org/10.5539/ass.v9n2p53

Griffiths, R. (1990). Speech rate and nonnative speaker comprehension:

a
preliminary study in the timebenefit analysis. Language Learning, 311-336. https://doi.org/10.1111/j.14671770.1990.tb00666.x 
Renandya, W. \& Farrell, T. (2011). Teacher, the tape is too fast! Extensive listening in ELT. ELT Journal, 65(1), 52-59. http://dx/doi.org/10.1093/elt/cc q015

Renandya, W., \& Jacob, G. M. (2016). Extensive reading and listening in the L2 classroom. In Renandya, W., and H. P. Widodo (Eds.), English Language Teaching Today (pp. 97110). Switzerland: Springer International Publishing. https://doi.org/10.1007/978-3319-38834-2 8

Takaesu, A. (2013). TED Talks as an extensive listening resource for EAP students. Language Education in Asia, 4(2), 150-162. http://dx.doi.org/10.5746/LEiA/13/ V4/I2/A05/Takaesu

Vo, Y. (2013). Developing extensive listening for EFL learners using internet resources. Hawaii Pacific University TESOL Working Papers Series 11, 29-51.
Widodo, H. P., \& Cirocki, A. (2015). Video-mediated listening tasks in the EAL classroom: A sociopragmatic perspective. The Asian EFL Journal, 81, 62-90.

Yeh, C-C. (2013). An investigation of a podcast learning project for extensive listening. Language Education in Asia, 4(2), 135-149. http://dx.doi.org/10.57 46/LEiA/13/V4/I2/A04/Yeh

Yoshida, K. (2013). Reconsidering Japan's English Education based on the principles of purilingualism. In Selected Papers from the Twentysecond International Symposium on English Teaching (pp. 121-129). English Teachers' Association Republic of China. Crane: Taipei.

Zhao, Y. (1997). The effects of listeners' control of speech rate on second language comprehension. Applied Linguistics, 18(1), 49-68. https://doi.org/10.1093/applin/18.1. $\underline{49}$ 
30 JURNAL PENDIDIKAN EDUTAMA, Vol.6., No.2 Juli 2019 